\title{
How venture capitalists evaluate young innovative company patent portfolios: empirical evidence from Europe
}

How VCs evaluate YIC patent portfolios
Received 19 October 2018 Revised 17 June 2019 6 December 2019 29 January 2020 Accepted 2 February 2020

\begin{abstract}
Purpose - This paper analyzes the importance given by venture capital (VC) firms to the different characteristics of the patent portfolio of a young innovative company (YIC). In an attempt to go beyond previous studies, the authors argue that not only is the size of a technological portfolio significant but also its nature. It is also examined whether the correlation between patents and VC financing varies across different industrial sectors and over different rounds of VC investments.

Design/methodology/approach - The empirical analysis has focused on a sample of 1,096 European YICs between the years 2010 and 2014. Target companies were identified in the monthly bulletins of Go4Venture, which reported the largest European deals and gathered information on the amount of VC financing. Additional data was derived from FinSMEs and crunchbase. Industrial sectors were differentiated according to their ability to appropriate the returns of innovation by relying on patent protection mechanisms. A multivariate regression framework at the patent family level was adopted to investigate empirical associations between the amount of VC financing and the characteristics of a YIC's patent portfolio.

Findings - The results confirm the positive value of patents. Both the size and the characteristics of a YIC patent portfolio have been found to be positively associated with the total amount of VC financing. Additionally, the correlation between a YIC patent portfolio and VC investment varies across industries and over rounds of funding. Although the number of patents is positively correlated with VC investments in sectors with strong Intellectual Property (IP) regimes, the same does not apply to sectors characterized by lower patent intensity, where qualitative metrics seem to have a stronger correlation. Significant differences have also been found for the different rounds of VC investments.

Research limitations/implications - The limitations of this paper are related to data availability. Empirical associations have been investigated, but causal effects cannot be ascertained in this framework. The authors focused on a sample of firms that received VC funding. Several transactions were excluded, due to a lack of specifications pertaining to the round series. Furthermore, a number of potential drivers of the financed amounts, such as variables related to the founder or the management team, have not been considered in this study.

Practical implications - For firms operating in sectors with weak IP regimes, patents are positively associated with attracting equity capital, if they are the output of R\&D collaborations and have higher technical merit. In industries where patent intensity is higher, patent portfolio size matters more than quality. This suggests that VC investors award innovation quality to cases in which patenting is less frequent. Since the results indicate that positive associations between patenting and VC financing are more significant in later stages, managers should plan their patenting strategy in advance to reap the related benefits, and then collect the premium at later VC stages. Originality/value - In this paper, the importance given by VC firms to different characteristics of a YIC patent portfolio has been analyzed in terms of size, quality, and complexity. While previous empirical analyses mainly focused on a single sector, the authors have examined whether the relevance of patents for VC financing
\end{abstract}

\section{JEL Classification - O31, G24, L26}

(C) Federico Caviggioli, Alessandra Colombelli, Antonio De Marco and Emilio Paolucci. Published by Emerald Publishing Limited. This article is published under the Creative Commons Attribution (CC BY 4.0) licence. Anyone may reproduce, distribute, translate and create derivative works of this article (for both commercial and non-commercial purposes), subject to full attribution to the original publication and authors. The full terms of this licence may be seen at http://creativecommons.org/licences/by/4.0/ legalcode

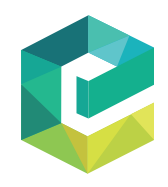

International Journal of Entrepreneurial Behavior \& Vol. 26 No. 4,2020 pp. $695-721$ 
IJEBR

26,4 decisions varies across industries and over different rounds of investment. The geographical coverage of the sample is another novelty of the paper. Previous works focused on a limited number of countries, whereas this research has considered firms operating in several European countries.

Keywords Venture capital, Young innovative company, Start-up, Patent portfolio, Asymmetric information, Signaling

Paper type Research paper

\section{6}

\section{Introduction}

Young innovative companies (YICs) have attracted increasing interest from both academic scholars and policymakers, as they are considered key drivers of innovation activities, new job creation, and, in turn, economic growth (Schneider and Veugelers, 2010). One of the main barriers to the growth of YICs is their access to finance. YICs are usually subject to financial constraints and have to rely on external capital to finance their innovation activities (Atherton, 2012; Macht and Robinson, 2009). Although not all YICs proactively seek venture capital (VC) financing, and among those that look for VC support, only a few obtain it (Colombo et al., 2018; Fried and Hisrich, 1994; Petty and Gruber, 2011), it can be a key form of financing for young firms with a high growth potential (Häussler et al., 2014; Lahr and Mina, 2016; Pandey and Jang, 1996). As a consequence, VC-backed companies have specific characteristics and represent an interesting field of study to identify the drivers of VC investment decisions and, in turn, to derive important implications for entrepreneurship and innovation policies.

Because of the presence of asymmetric information, $\mathrm{VC}$ firms encounter difficulties in assessing the quality of young companies. It is in fact difficult for outsiders to assess intangible assets, such as know-how, human capital, and technologies (Lev, 2000). YICs thus need to be able to communicate the quality of their ventures to VCs. In addition to their essential role as legal protection from imitation by competitors, patent rights can also be considered, on the one hand, as an important mechanism to signal the quality of a YIC and, on the other they are important marketable assets (e.g. Caviggioli et al., 2017; Ciaramella et al., 2017; De Marco et al., 2017; Figueroa and Serrano, 2019; Serrano, 2010). Although the effect of patenting on VC is generally considered relevant (Baum and Silverman, 2004; Conti et al., 2013; Mann and Sager, 2007; Munari and Toschi, 2015) [1], our understanding of which patent characteristics matter is still at a preliminary stage.

This paper contributes to such a debate and seeks to shed further light on the relationship between patent activities and VC financing. In an attempt to go beyond previous studies, the authors argue that not only is the size of a technological portfolio significant but also its nature. As the distribution of the economic value attributed to patents is extremely skewed (Scherer and Harhoff, 2000), and only a small fraction of protected inventions is truly of high technical merit, it may be expected that, in order to take their investment decisions, VC firms go beyond the mere patent stock and evaluate various characteristics related to the technological portfolio of YICs. This issue has been almost totally neglected in the extant literature. The present study is aimed at filling such a gap and at investigating the relationship between the features of the patent portfolio owned by a YIC and the total amount of VC funding over time. The main proposition of the authors is thus: it is not only the number of patents owned by a YIC that affects the total amount of $\mathrm{VC}$ financing but also the characteristics of its patent portfolio.

The paper contributes to the extant literature in the following respects. First, the importance given by VC firms to different characteristics of a YIC patent portfolio is analyzed in terms of size, quality and complexity. Second, while each of the previous empirical analyses mainly focused on a single industrial sector (e.g. Bertoni and Tykvová, 2015), this paper examines whether the relevance of patents for VC financing decisions varies across different industries. In fact, it is likely that the importance given to patents is not the same in sectors 
that have distinctive Intellectual Property (IP) regimes and mechanisms. Third, the authors assess whether the importance of patent rights for financing decisions varies across different rounds of investment. It is expected that the size and the value of the patent portfolio of a company increase over time and that such an innovation capacity is positively evaluated by VCs.

The empirical analysis has focused on a sample of more than 1,000 European YICs that received VC funding between the years 2010 and 2014. Previous works focused on a limited number of countries, and only in a few cases did they consider more than one state at the same time (Häussler et al., 2014; Lahr and Mina, 2016; Munari and Toschi, 2015). This research extends the examined geographical scope by considering companies that operate in several European countries [2].

The results of the analysis confirm that both the number of patents owned by YICs and several characteristics of their patent portfolio, related to both the quality and the complexity of the innovative output of the YICs, are significantly correlated to the total amount of VC financing. However, the VC funding premium associated with the patenting activities and their characteristics varies across industries and rounds of funding. More in detail, we have observed a positive signal from the size of the portfolio of inventions in sectors with strong IP regimes and in later financing stages but not in the early ones. As far as the complexity measures are concerned, larger amounts of seed investments are associated with YICs that have less science-based inventions (i.e. closer to actual applications). The technological scope is positively related to $\mathrm{VC}$ funding in A-series stages, thus suggesting a premium for potential redeployability, while it is negatively related to the amount invested in later stages. The evidence suggests that investors are more likely to invest the largest amount that is typical of the later stages whenever the target YIC enters the expansion phase with more specific technologies and products and on a recognized market. Different quality measures have been found to be positively related to the financed amount across all the stages and sectors, but in particular at later stages, when the investment is much larger, and in weak IP regimes: quality signals mitigate the risk perceived by the investors.

The remaining part of the paper is organized as follows. The Research framework section discusses the theoretical basis that underpins the relationship between patenting activities and VC financing and presents the hypotheses. The Data collection and methodology section describes the sources and the empirical approach, while the findings of the econometric analyses are presented in the Results section. Finally, the last section provides the concluding remarks.

\section{Research framework}

The value of patents

The extant literature is unanimous in considering that the $\mathrm{VC}$ investing mechanism is characterized by information asymmetries between the investee and the investor. This is particularly true for SMEs and new technology-based firms (Baum and Silverman, 2004; Hoenen et al., 2014; Kolympiris et al., 2017; Lahr and Mina, 2016; Nadeau, 2010; Zhou et al., 2016). A target firm generally holds more information than the available investors, who are not able to accurately evaluate its potential or the value of its know-how, inventions, prototypes and technologies (Häussler et al., 2014). The investors bear the risk of having very few elements to assess the economic value of firms with a short history that operate in a new field, without audited financial statements or market results (Lahr and Mina, 2016). Thus, VC firms have to face different kinds of risks, such as the technology risk, the market risk and the financial risk. Both firms and investors are interested in alleviating the investment selection risks associated with information asymmetry (Spence, 1973). Firms can try to reduce the asymmetry by communicating their value to the investors in a credible way, or, in other

\author{
How VCs \\ evaluate YIC \\ patent \\ portfolios
}

697 
IJEBR

26,4

698 words, by providing effective signals (Busenitz et al., 2005; Hoenen et al., 2014; Zhang and Wiersema, 2009). This process is described in the signaling theory (Spence, 1973, 2002), where effective signals are visible and costly, and, as a result, low-quality agents are not able to afford them. From the perspective of VC investors, signaling helps them in the screening process and drives their investment decisions toward more valuable firms (Higgins and Gulati, 2006). According to this line of reasoning, signals are considered a key mechanism to reduce information asymmetries (Hsu, 2007; Janney and Folta, 2003).

In this framework, we have focused on the signaling value of a patent, which reduces information asymmetry with potential investors, although the original purpose of a patent is to gain an economic value from the monopolistic market rights that come with it. Furthermore, patents can be strategically used by start-ups to gain other types of benefits, such as to enhance reputation, to create barriers with the purpose of increasing imitation costs, and to build up bargaining chips to be used in establishing alliances or collaterals to attract sources of finance (Helmers and Roger, 2011; Audretsch et al., 2012; Hoenen et al., 2014; Hoenig and Henkel, 2015; Soöderblom et al., 2015). VCs can thus evaluate patents in terms of the economic value that derives from their strategic use.

Previous studies focused on different mechanisms that companies could trigger to communicate their value to $\mathrm{VC}$ investors. Some of these mechanisms are related to the experience and characteristics of the entrepreneur or the management team (Colombelli, 2015; Engel and Keilbach, 2007; Higgins and Gulati, 2006; Hoenig and Henkel, 2015; Hsu, 2007; Lam, 2010; Nadeau, 2010; Zhang and Wiersema, 2009; Zhou et al., 2015). Other signals are associated with the initial strategy of the firm, such as forming an alliance with a research partner (Hoenig and Henkel, 2015; Stuart et al., 1999) or jointly filing trademarks (Zhou et al., 2016), while others are associated with the intensity of research, such as R\&D expense, R\&D personnel or being a university spin-off (Baum and Silverman, 2004). Finally, signals might be connected directly to the presence of technological or product innovations that are protected by patent rights (Conti et al., 2013; Gredel et al., 2012; Hoenig and Henkel, 2015; Hsu and Ziedonis, 2013; Long, 2002; Mann and Sager, 2007; Nadeau, 2010; Veer and Jell, 2012).

Patent management experience, R\&D alliances (Hoenig and Henkel, 2015; Knockaert et al., 2010; Smith and Cordina, 2015), and the presence of prototypes (Audretsch et al., 2012) have been found to be the most valued mechanisms for investors. Management experience is in fact easy to assess (Knockaert et al., 2010; Smith and Cordina, 2015) and R\&D alliances are visible, costly, and highly correlated with technology quality and competence (Hoenig and Henkel, 2015), while the presence of prototypes suggests the feasibility of a new technology (Audretsch et al., 2012). Although relevant, such resources are subject to changes: the management experience is embedded in people who might leave the company; the collaboration with R\&D partners might terminate or not be renewed earlier than expected, and this can lead to ownership issues; the development of prototypes might suffer from reverse engineering, due to information leakage, or be overtaken by a newcomer or an incumbent with a faster development process. On the contrary, patents can be created at a very early stage of the firm's lifecycle and do not change over time (Nadeau, 2010). Moreover, Conti et al. (2013) showed that the effect of patents is more valuable for VC investors than other resources, such as founder, friend, and family investments. Patents satisfy the requirement of being considered as quality signals: they are easily observable, costly to acquire (Graham et al., 2009), and provide a mechanism by which quality types can be sorted (Long, 2002). Through patents, VC investors can be informed on whether a company is well managed, operating in a market niche (Lemley, 2000), and developing research activities at a certain pace (Long, 2002). The presence of patents also provides VC investors with the option of recovering some residual values in the case of failure (Nadeau, 2010). Furthermore, patents are signals of particular value, since they are regulated by institutional practices that make the evaluation of the receiver less subjective (Hoenen et al., 2014; Janney and Folta, 2003). 
In spite of the number of studies that have empirically investigated the role of patents as a signal, the evidence is still scarce (Hoenen et al., 2014) and rarely debated, due to the mixed results that have been obtained. As noted by Hoenen et al. (2014), several studies have found evidence of a positive correlation between patents and both the performance and growth of firms, due to the acquired monopolistic position, future technology options, and higher bargaining power with partners, investors, and other stakeholders (Baum and Silverman, 2004; Gans, 2002; Giuri et al., 2007; Lerner, 1994). Agostini et al. (2015) showed that not only the size of the patent portfolio but also the quality of the protected inventions appear to be relevant for the performance of firms, especially for SMEs.

Moving from the relationship between patents and firm performance to the effect of patenting on the decisions of investors, previous works again provided contrasting results. In this stream of research, different variables have been employed as proxies of the investment decision, and the analyses have coherently been focused on a sample of VC-backed companies or they have been compared with non-VC-backed firms. The signaling effect of patenting has been studied in terms of the probability of obtaining VC financing (Conti et al., 2013; Hsu, 2007; Lerner, 1994), the likelihood of attracting a prominent VC investor (Hsu, 2007), the ability to attract financing earlier (Häussler et al., 2014), the total amount of VC received (Baum and Silverman, 2004; Hoenen et al., 2014; Hsu, 2007; Mann and Sager, 2007; Nadeau, 2010; Zhou et al., 2016), the number of VC rounds, the exit status and IPO pricing (Hsu, 2007; Mann and Sager, 2007), and the number of VC investors (Nadeau, 2010).

Most of the previous studies found a positive correlation between patents and VC investments (Audretsch et al., 2012; Baum and Silverman, 2004; Conti et al., 2013; Engel and Keilbach, 2007; Häussler et al., 2014; Hsu, 2007; Mann and Sager, 2007; Popov and Roosenboom, 2012). However, some others did not find such a convincing result, and in some cases, pointed in the opposite direction. According to Deeds et al. (1997) and Stuart et al. (1999), there is no robust evidence of a positive signaling effect of patents on the expectations of investors at the IPO time. Another stream of research obtained evidence of a negative relationship between patenting and investment decisions (Knockaert et al., 2010). In the work of Smith and Cordina (2015), interviews with VC investors revealed that $79 \%$ of the respondents did not consider the role of patents as a primary and reliable signal of technological value.

\section{Research questions}

\section{Patent portfolio characteristics}

The heterogeneous results discussed so far suggest that the number of patents owned by a technology-based company may not be sufficient to convey a meaningful signal to the investors, and that the characteristics of the patent portfolio may be correlated to the total amount of VC financing. In this respect, only a few studies have tried to go beyond the mere number of patents to assess the relationship between innovation and VC funding. Some authors included the number of received citations as a proxy of the patent value, and contrasting results were found (Dushnitsky and Lenox, 2005; Häussler et al., 2014; Hoenen et al., 2014). Häussler et al. (2014) investigated the correlation between the milestones of the patenting process and the timing of VC financing and found evidence of the presence of delays whenever a negative event occurs. Lerner (1994), Munari and Toschi (2015) also included the patent scope in their empirical models with different findings.

This contrasting evidence leads to the first research question. The authors in particular try to provide further evidence on the presence of the signaling and the economic effect of patents of attracting more $\mathrm{VC}$ financing when patent level features are considered. In order to improve the understanding of such a mechanism, various qualitative characteristics of the patent portfolio have been included - in terms of technological complexity and value - that

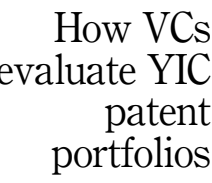

699 
IJEBR

26,4

700 investors might take into account in their decisions. These dimensions of the patent portfolio could in fact provide VC firms with useful information to alleviate the risks associated with information asymmetries, such as technology risks, market risks and financial risks.

Within the wide literature that is available, the work by van Zeebroeck and van Pottelsberghe de la Potterie (2011) provides a comprehensive review and distinguishes the characteristics of patent-protected inventions over several dimensions. According to this study, complexity can be measured by the number of backward patent and nonpatent citations, inventors and reported International Patent Classification (IPC) subclasses. The dimension of complexity is relevant for the present analysis as, when dealing with complex technologies, firms may experience more difficulties in communicating their value for transaction purposes (Caviggioli and Ughetto, 2016; Tietze, 2012) and in attracting VC investors (Heeley et al., 2007). A key characteristic that a firm needs to communicate to potential investors is the technical novelty of its inventions. In the literature, the number of backward citations is used to proxy the technical novelty of the patents (Reitzig, 2003). Hence, the analysis is expected to report a negative relationship between the amount of financing and the number of backward citations. Technological complexity is also positively related to the number of inventors working on the technology: larger teams suggest the need to combine knowledge and expertise (van Zeebroeck and van Pottelsberghe, 2011). The feasibility of a technology has been found to be an important signal to attract VC investments (Audretsch et al., 2012). The citations to scientific knowledge represent how much closer the protected invention is to basic research (Meyer, 2000) [3] and can therefore be considered a proxy of feasibility in the sense that the more the protected invention is applied, the more feasible and attractive it is for VC investors. Consequently, a negative relationship between scientific knowledge citations and VC financing can be expected. The technological scope is the propensity to be transversal or multipurpose with applications in multiple technological domains (Lerner, 1994). Previous studies about the relationship of technological scope with VC financing found mixed results: a positive correlation was found in Lerner (1994) and in the outcome of the survey to VC investors carried out by Smith and Cordina (2015). Munari and Toschi (2015) focused on the nanotechnology sector and did not find any support for the positive relationship with patent scope, probably due to the uncertainty of patenting in such a new sector. On the one hand, VC investors might prefer a very focused innovation, while on the other they might put more value on the potential redeployability of the protected technology.

The quality of patented inventions can instead be measured over three dimensions. The first concerns the patent ownership structure, in terms of the number of assignees: patents with more assignees are more likely to be the result of R\&D collaborations (Giuri et al., 2007; Guellec and de la Potterie, 2000) and thus of higher relevance. To the best of the authors' knowledge, the previous works on $\mathrm{VC}$ and patenting did not take into consideration such a quality variable. As R\&D collaborations are valued by VC investors (Hoenig and Henkel, 2015; Smith and Cordina, 2015; Stuart et al., 1999), a positive relationship with the amount of VC financing can be expected. Second, the technical merit of patents is proxied by the number of received citations (see, among the several works, those of Harhoff et al., 1999; Reitzig, 2003; Trajtenberg, 1990). Such a measurement was empirically found to be strongly correlated with the underlying economic value of its corresponding invention (Scherer and Harhoff, 2000). Accordingly, this measure has been employed to distinguish between the value of the underlying invention and the signaling effect of patents, as in Hoenen et al. (2014). As far as the VC literature is concerned, Häussler et al. (2014) found no significant correlation between the few previous works that included forward citations in their models, while Dushnitsky and Lenox (2005) found a positive relationship with the VC amount, but only in industries with a weak IP regime. Finally, the geographical scope or the number of jurisdictions in which 
patent protection is sought is closely correlated with the quality of the underlying invention, as the corresponding applicant commits to paying maintenance fees in each designated national patent office (Harhoff et al., 1999; Santarelli and Lotti, 2008). This metric has not been empirically investigated in VC literature, but Smith and Cordina (2015) interviewed 21 experts about the relevance of different patent characteristics for VC investment decisions, including family size, which scored 3.43 on a scale from 0 to 5 . Furthermore, the geographical scope could represent a proxy of early internationalization, a relevant characteristic of YICs (Bloodgood, 2006). It is expected to be positively related to the VC amount.

\section{Sectors}

Another issue is related to industrial sector specificities. Most of previous empirical works focused on specific sectors, such as semiconductors (Hsu and Ziedonis, 2013), software (Mann and Sager, 2007), biotechnology (Baum and Silverman, 2004; Häussler et al., 2014; Hoenen et al., 2014; Mann and Sager, 2007), nanotechnology (Munari and Toschi, 2015), and greentech (Bergset, 2018). Most of the industrial subjects of these analyses are characterized by a strong IP regime, where patents are fundamental to defend inventions, appropriate the return from innovation, and sustain competitive advantage (Gans, 2002).

However, the results of previous studies have revealed that the propensity of firms to patent is quite heterogeneous across industries (Arundel, 2001; Cohen et al., 2000; Hall et al., 2014; Pakes and Griliches, 1980). This is due to the fact that, in sectors where knowledge is highly codified (e.g. in the pharmaceutical and biotechnology fields), patents may offer stronger protection from imitation (Hall et al., 2014). These sectors usually show a high patent intensity, i.e. a higher number of filings per firm on average. On the contrary, in other sectors (e.g. food, fashion, architecture, financial services), patents are less effective and firms rely more on other mechanisms, such as secrecy and lead times or reverse engineering and inventing-around, in order to appropriate the returns from their innovation (Arundel, 2001; Cohen et al., 2000; Hall et al., 2014). These sectors thus show a low patent intensity.

Nadeau (2010) selected high-performing firms from seven technology sectors (i.e. Biotechnology, Communications, Computer Hardware, Internet, Medical and Health, and Semiconductor and Electronics) and found that the patenting activity and VC investor intensity were very heterogeneous. Hence, there seems to be a connection between the signaling effect of patents and the patenting intensity of the examined industries. A similar indication was given in the work of Dushnitsky and Lenox (2005): although focused on corporate $\mathrm{VC}$, with all of its peculiarities, they did not find a positive correlation between patent value and VC in industries characterized by a strong IP regime.

According to this line of reasoning, it may be expected that, since the relevance of holding patents differs across sectors, the relationship with VC financing will also vary across sectors. The authors, thus, have attempted to disentangle the differential role of the IP regime and investigate whether the signaling value of patents changes when firms in industries characterized by high or low patent intensity are considered.

In sectors characterized by weak IP regimes, where competitors might quickly and easily imitate the successful products and knowledge generated by innovators, the outcomes and profits of R\&D activities are not fully appropriable via IP rights. In such conditions, patents are less valuable per se, and their signaling effect could have less importance for $\mathrm{VC}$ funding. However, the presence of patented technologies could be positively valued by VC investors whenever they proxy higher levels of collaborative R\&D, early internationalization or inventiveness of the focal company. On the contrary, in sectors characterized by strong IP regimes, an increased patenting activity is expected to have a positive association with VC financing, both in terms of quantity and quality indicators.

\author{
How VCs \\ evaluate YIC \\ patent \\ portfolios
}


IJEBR

26,4

702

\section{Rounds}

The different stages of VC financing are characterized by diverse risk levels, associated with firm growth, and the potential expected returns (Flynn and Forman, 2001). Initial seed rounds are on average smaller, are aimed at financing starting activities, and are endowed with a higher risk. A-rounds are generally early-stage funds which support production, market entry, or R\&D activities (Jeng and Wells, 2000). Later stages are aimed at expansion or company acquisition, and they are larger.

Only a few studies have examined the relationship between patents and VC financing stages. These works have provided evidence of a differential relationship between patenting and $\mathrm{VC}$ financing when either early or later stages are considered, although the results have not been conclusive. Mann and Sager (2007) found that patenting is associated with a greater likelihood of receiving financing in later $\mathrm{VC}$ rounds, when companies have started to generate revenues that patents might protect, rather than in the seed or early stages. Hoenen et al. (2014) and Hsu and Ziedonis (2013) also found contrasting results. According to these studies, early rounds are associated with stronger signaling effects. One reason for this might be a reduction in the information asymmetries between investors and investees, and in the signaling power of patents, as suggested by Hoenen et al. (2014). However, the authors noted that the evidence was not robust and stated that further research on this issue was badly needed.

In view of this evidence, the authors have here investigated whether the signaling value of patents changes when the different stages of financing are considered.

\section{Data collection and methodology \\ Data}

The main data source is VCStar, an original database which contains information on VC deals and VC funding transactions that took place between the years 2010 and 2014. The database combines different data sources. The target companies were identified in the monthly bulletin of Go4Venture [4], which reported the largest European deals and gathered information on the amount of $\mathrm{VC}$ financing. More than 1,500 firms with European headquarters or operating branches were examined. They received $\mathrm{VC}$ financing during the aforementioned time period, which was limited to 2014 in order to deal with truncation due to the availability of patent publications at the moment of data collection and to account for potential delays in the updating of the electronic repositories. The selected firms received at least one round of $\mathrm{VC}$. Information on the companies (i.e. foundation, location, and industry) and on the received $\mathrm{VC}$ rounds (i.e. amount and series) were completed by comparing additional sources, such as FinSMEs, crunchbase [5], and other web resources [6]. The data integration was prevalently automated by matching the company names and, in addition, an extensive manual check and cleaning were performed by triangulating the collected information with the results of searches on public websites (e.g. the official websites of the companies, news repositories, Wikipedia, etc.).

The data cleaning process excluded several firms, because of missing information in relevant fields (e.g. foundation year, type of VC round [7], sector, etc.), and this led to a final sample of 1,096 YICs (with an average age of 4 years) and 1,988 observations of VC financing. Some transactions were reported in different currencies from USD, and the amounts were therefore converted by applying the exchange rate at the date of the investment, thus implementing the process described in Zhou et al. (2016). The total amount of the examined transactions is 18.2 billion USD, consistent with the value of circa 21 billion EUR reported by Invest Europe [8], formerly known as European Private Equity and Venture Capital Association (EVCA) which represents Europe's private equity, VC firms, and infrastructure sectors, as well as their investors. The final sample is composed of companies having their 
headquarters or a branch in EU-28, Norway or Switzerland. As expected, the most represented country is the United Kingdom (34.1\% of the sample), followed by Germany $(14 \%)$ and France $(12.3 \%)$.

The analysis of the identified $1,988 \mathrm{VC}$ rounds shows that each round is on average worth 9.2 million USD. Half of the firms fell into the sample with only one round $(52 \%)$, while almost all $(97 \%)$ fell into the sample with less than five rounds.

As far as the type of rounds identified in the sample are concerned, most of the sample $(40 \%)$ is made up of A-series rounds, $22 \%$ of seed financing, and the residual $38 \%$ includes B, $\mathrm{C}$, and later stages rounds. As can be observed in Table 1 , the seed stages are characterized by the lowest average amount of VC (1.4 million USD), A-series rounds by a medium level (6.5 million USD), and later stages by much higher amounts (16.9 million USD).

The Derwent Innovation patent database (provided by Clarivate Analytics) was searched for each of the selected companies and the corresponding patent portfolio was constructed. Accurate manual searches in the patent assignee field pertaining to the company names have been performed by controlling for name changes, spelling variations, and types of company (e.g. $L T D, I N C$, etc.). The actual correspondence between the title of the retrieved patents and the company activities has been checked in order to avoid false positive matches [9]. The process considered all the patent applications, and not only the granted ones, with the aim of capturing all the signaling effects. Indeed, previous studies suggested that the relationship between applications and VC financing was higher than that of grants (Baum and Silverman, 2004; Cockburn and MacGarvie, 2009; Häussler et al., 2014). Since a patent examination takes several years to reach a final decision, it is likely that the decisions of investors are prevalently based on pregrant filings, and firms are incentivized to reveal information through pending applications (Stuart et al., 1999; Smith and Cordina, 2015). The patents in each portfolio were aggregated according to their INPADOC family [10]. More than one-third $(37.6 \%)$ of the identified VC deals occurred at a point in time in which the financed companies were associated with at least one patent filing. Of the considered 1,096 YICs, $384(35 \%)$ hold at least 1 patent and are therefore considered as YICs. The size of the average portfolio of a funded company with at least one patent is 3.2 families.

In order to account for the differential role of the IP regime on VC investment decisions, the sampled industrial sectors were differentiated according to their ability to appropriate the returns of innovation by relying on patent protection mechanisms. In other words, two categories have been identified, which are defined according to the average number of patented inventions per firm in the field, with 3 patent families being set as the threshold [11]. In so doing, the IP regimes are clustered according to their patent intensity level [12] (see Table 2 for details). The two largest sectors in the sample are "Internet" (34\% of firms) and "Software, Mobile" (26\%), both of which are included in the group characterized by a weak IP regime and when aggregated, represent $74 \%$ of the examined sample. Among the fields characterized by a strong IP regime, the most frequently represented is the one that includes "Pharma, Biotech, Medical technologies" (8\%). Table 3 summarizes the descriptive statistics of the sample and distinguishes between the companies with high and low IP regimes. The

\begin{tabular}{lrrrrr}
\hline Subsample & Perc & Mean & Std. dev & Min & Max \\
\hline Seed rounds & 22 & 1.322 & 1.256 & 0.01 & 10.59 \\
A-rounds & 40 & 6.297 & 8.992 & 0.02 & 124.00 \\
Later stages & 38 & 16.752 & 25.005 & 0.14 & 374.20 \\
All rounds & 100 & 9.152 & 17.570 & 0.01 & 374.20
\end{tabular}

Note(s): The full sample includes 1,988 rounds
How VCs
evaluate YIC
patent
portfolios

703
Table 1. Descriptive statistics on the amount of $\mathrm{VC}$ financing (in million USD) by type of round 
IJEBR

26,4

704

analysis of the YIC patent portfolios confirms the fitness of the process adopted to associate a sector to a strong or weak IP regime (the patent matching procedure is described in the following paragraphs). In fact, the YICs in the weak IP regime group have on average 1.5 patented (or pending) inventions, while those in the strong IP regime group have 8.3 inventions.

In terms of received $\mathrm{VC}$, the firms belonging to the strong or weak IP regimes raised similar amounts on average, that is, of 17.3 and 16.4 million USD, respectively (the $t$-test reported no statistically significant difference).

The bibliometrics relevant to the analyses, such as the number of inventors, the number of IPC codes, and the number of citations were also collected for each patent from Derwent Innovation. The bibliometrics of a patent characterize the invention over different technological dimensions and can thus be explored to provide a better specification of the

\begin{tabular}{|c|c|c|c|c|c|c|}
\hline Industrial sector & $\begin{array}{l}\text { Nbr. } \\
\text { of firms }\end{array}$ & $\begin{array}{l}\text { Perc. on } \\
\text { tot. firms }\end{array}$ & $\begin{array}{l}\text { Nbr. } \\
\text { of families }\end{array}$ & $\begin{array}{l}\text { Perc. on } \\
\text { tot. fam }\end{array}$ & $\begin{array}{l}\text { Avg. } \\
\text { families per } \\
\text { firm }\end{array}$ & $\begin{array}{l}\text { Avg. yearly } \\
\text { fam. per } \\
\text { firm }\end{array}$ \\
\hline \multicolumn{7}{|l|}{ Low patent intensity } \\
\hline Consulting & 4 & 0.4 & 0 & 0.0 & 0.0 & 0.00 \\
\hline Sport, Food, Services & 5 & 0.5 & 0 & 0.0 & 0.0 & 0.00 \\
\hline $\begin{array}{l}\text { Art, Fashion, Design, } \\
\text { Architecture }\end{array}$ & 7 & 0.6 & 0 & 0.0 & 0.0 & 0.00 \\
\hline Travel, Tourism & 19 & 1.7 & 0 & 0.0 & 0.0 & 0.00 \\
\hline Education & 7 & 0.6 & 3 & 0.1 & 0.4 & 0.09 \\
\hline Gaming & 25 & 2.3 & 16 & 0.5 & 0.6 & 0.13 \\
\hline Advertising, Marketing & 55 & 5.0 & 38 & 1.1 & 0.7 & 0.11 \\
\hline Content, Media & 11 & 1.0 & 11 & 0.3 & 1.0 & 0.21 \\
\hline Internet & 376 & 34.3 & 444 & 12.6 & 1.2 & 0.25 \\
\hline Financials & 23 & 2.1 & 30 & 0.9 & 1.3 & 0.17 \\
\hline Software, Mobile & 287 & 26.2 & 673 & 19.2 & 2.3 & 0.33 \\
\hline \multicolumn{7}{|l|}{ High patent intensity } \\
\hline Security & 8 & 0.7 & 27 & 0.8 & 3.4 & 0.42 \\
\hline Telecommunications, IT & 5 & 0.5 & 19 & 0.5 & 3.8 & 0.88 \\
\hline Health care & 28 & 2.6 & 109 & 3.1 & 3.9 & 0.75 \\
\hline $\begin{array}{l}\text { Pharma, Biotech, Medical } \\
\text { technologies }\end{array}$ & 88 & 8.0 & 558 & 15.9 & 6.3 & 1.07 \\
\hline Cleantech & 61 & 5.6 & 565 & 16.1 & 9.3 & 1.31 \\
\hline Manufacturing, & 19 & 1.7 & 200 & 5.7 & 10.5 & 1.47 \\
\hline $\begin{array}{l}\text { Hardware, Electronics, } \\
\text { Semiconductors }\end{array}$ & 68 & 6.2 & 817 & 23.3 & 12.0 & 1.60 \\
\hline
\end{tabular}

Table 3.

Summary statistics of patenting activities and the amount of $\mathrm{VC}$ financing (in million USD) broken down by the appropriability level of the considered industry

\begin{tabular}{lcrcrcrc}
\hline $\begin{array}{l}\text { Patent } \\
\text { intensity }\end{array}$ & Nbr. of firms & Perc & Nbr. of patents & Perc & Nbr. of families & Perc & $\begin{array}{c}\text { Avg. amt. of VC } \\
\text { Financing }\end{array}$ \\
\hline Low intensity & 819 & 75 & 4,573 & 28 & 1,215 & 35 & 16.4 \\
High intensity & 277 & 25 & 11,868 & 72 & 2,295 & 65 & 17.3 \\
All industries & 1,096 & 100 & 16,441 & 100 & 3,510 & 100 & 16.6 \\
\hline
\end{tabular}


potential signaling effect of patents on VC. Since patent families are the selected unit of analysis, when several patents belong to the same patent family, backward and forward citations of each family member have been aggregated by excluding duplicate entries.

\section{Methodology}

In order to analyze the relationship between the characteristics of a YIC patent portfolio and the total amount of VC financing, a multivariate regression framework has been adopted, where the unit of analysis is the funding round. The following baseline equation has been used:

$$
\text { FinancedAmt } t_{i, t}=\alpha+\beta X_{i, t}+\gamma C_{i, t}+\epsilon_{i, t}
$$

In the previous equation, the logarithm of the total amount of VC financing (i.e. FinancedAmt, the dependent variable, as in Hoenen et al., 2014 and Zhou et al., 2016) is modeled as a function of the characteristics of the patent portfolio owned by the financed company at the time of investment, $X_{i, t}$ is a vector of the explanatory variables, and $C_{i, t}$ is a set of controls. The features of the patent portfolio are measured by first aggregating data at the patent family level and then by computing averages at the firm level in each funding round.

The analyzed sample is an unbalanced panel dataset. In order to consider potentially unobserved variance at the firm level, linear regression estimations have been carried out with standard errors that allow for intra-firm correlations. The regression analyses have been replicated over the whole sample, and over subsamples defined by the different IP regimes and the $\mathrm{VC}$ rounds. The explanatory and control variables included in the model and their measurement methods are described below.

Following the work by van Zeebroeck and van Pottelsberghe de la Potterie (2011), the patent portfolio dimensions of complexity and value have been operationalized through patent bibliometrics. Complexity is measured through four variables: novelty is evaluated with the number of backward patent citations (i.e. bwdPatCitsNbr), science basicness is proxied by taking into account the share of nonpatent citations with respect to the total number of backward citations (i.e. bwdPubCitsPerc), the size of the research team is assessed from the number of inventors (i.e. inventors $\mathrm{Nbr}$ ), and the technological scope is determined via the number of reported IPC subclasses (i.e. techScope). The quality of patented inventions is measured considering three variables: the ownership structure is proxied by the number of assignees (i.e. assignees $\mathrm{Nbr}$ ); the technical merit of the patents in a company's portfolio is proxied by the average number of received citations, weighted by the age of the patent to account for the different exposure times to collect citations (i.e. weiFwdCitsNbr); the geographical scope (i.e. geoScope) of an invention is operationalized with the number of publication countries in which patent protection is sought.

Several controls, ranging from the age of the investee, the previously received VC amount (i.e. pastFinAmt), the geographical location of the firm, and time and industry dummies have been applied, in accordance with previous studies (Hoenen et al., 2014; Hsu and Ziedonis, 2013; Mann and Sager, 2007; Zhou et al., 2016).

The measurement method and descriptive statistics are provided in Table 4 for each variable. Only the forward and backward citations show a non-negligible correlation in the correlation matrix (Table 5). This result is not surprising. The variance inflation factor analysis has been performed in order to verify that multicollinearity is not an issue in the data: the mean values for the baseline models range between 1.00 and 1.30. The authors also ran regressions in which the two highly correlated variables were included in different models, and similar results were obtained. In all model specifications, cluster-robust standard errors at the firm level have been to deal with the cases of companies involved in multiple financing rounds.

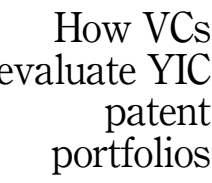

705 


\section{IJEBR 26,4}

706

\section{Results}

The main results of the ordinary least squares (OLS) regression estimations for the baseline equation are reported in Table 6 . The signaling effect of patenting was tested by employing a dummy for firms with at least one patent and for the total number of patented inventions at the date of the $\mathrm{VC}$ financing. Table 6 presents the results for the baseline equation computed on the full sample. The dependent variable is the logarithm of the VC amount. Columns 1 and 2 provide the results concerning the relationship between the size of a patent portfolio and VC financing, using two alternative proxies: famDum and cumulFamNbr, respectively. Columns 3 and 4 show the results for the full model, which also includes the characteristics of the

\begin{tabular}{|c|c|c|c|c|c|c|}
\hline Variable & Description & Obs & Mean & $\begin{array}{l}\text { Std. } \\
\text { dev }\end{array}$ & Min & Max \\
\hline financedAmt & $\begin{array}{l}\text { Logarithm of the financed amount in } \\
\text { million USD }\end{array}$ & 1,988 & 1.362 & 1.407 & -4.605 & 5.925 \\
\hline famDum & $\begin{array}{l}\text { Dummy equal to } 1 \text { if company } i \text { has filed } \\
\text { at least one patent at moment } t \text { and } \\
0 \text { otherwise }\end{array}$ & 1,988 & 0.365 & 0.482 & 0.000 & 1.000 \\
\hline cumulFamNbr & $\begin{array}{l}\text { Logarithm of the size of the patent } \\
\text { portfolio of company } i \text { at moment } t\end{array}$ & 1,988 & 0.609 & 0.986 & 0.000 & 4.905 \\
\hline pastFinAmt & $\begin{array}{l}\text { Previously financed amount in million } \\
\text { USD }\end{array}$ & 1,988 & 6.713 & 21.133 & 0.000 & 331.320 \\
\hline firmAgeAtDeal & Age of company $i$ at time $t$ & 1988 & 4.026 & 3.136 & 0.000 & 15.000 \\
\hline $\begin{array}{l}\text { Complexity } \\
\text { inventorsNbr }\end{array}$ & $\begin{array}{l}\text { Average number of inventors associated } \\
\text { to each patent family in the portfolio of } \\
\text { company } i \text { at time } t\end{array}$ & 726 & 2.465 & 1.264 & 1.000 & 11.000 \\
\hline techScope & $\begin{array}{l}\text { Average number of different IPC sub- } \\
\text { classes associated to each patent family } \\
\text { in the portfolio of company } i \text { at time } t \\
\text { (technology scope) }\end{array}$ & 726 & 1.840 & 0.749 & 1.000 & 4.667 \\
\hline bwdPatCitsNbr & $\begin{array}{l}\text { Average number of backward patent } \\
\text { citations associated to each patent family } \\
\text { in the portfolio of company } i \text { at time } t\end{array}$ & 726 & 11.959 & 14.139 & 0.000 & 245.000 \\
\hline bwdPubCitsPerc & $\begin{array}{l}\text { Average percentage of non-patent } \\
\text { citations with respect to the total number } \\
\text { of backward citations }\end{array}$ & 726 & 0.059 & 0.111 & 0.000 & 0.800 \\
\hline \multicolumn{7}{|l|}{ Quality } \\
\hline assignees $\mathrm{Nbr}$ & $\begin{array}{l}\text { Average number of assignees associated } \\
\text { to each patent family in the portfolio of } \\
\text { company } i \text { at time } t\end{array}$ & 726 & 1.175 & 0.571 & 1.000 & 12.000 \\
\hline geoScope & $\begin{array}{l}\text { Average number of jurisdictions } \\
\text { associated to each patent family in the } \\
\text { portfolio of company } i \text { at time } t\end{array}$ & 726 & 3.297 & 1.933 & 1.000 & 14.000 \\
\hline weiFwdCitsNbr & $\begin{array}{l}\text { Average number of received citations } \\
\text { associated to each patent family in the } \\
\text { portfolio of company } i \text { at time } t \text { (technical } \\
\text { merit) weighted on the age of filing }\end{array}$ & 726 & 0.580 & 0.810 & 0.000 & 11.250 \\
\hline
\end{tabular}

Table 4.

Summary statistics of the studied variables for each firm that received $\mathrm{VC}$ financing
Note(s): The values for the variables of the patent portfolio characteristics are available only for those companies having at least one patent at the date of the round of financing. For such reason, the variables from inventors Nbr to weiFwdCitsNbr show a smaller number of observations (726) than those calculated on the total sample (i.e. financedAmt, famDum, cumulFamNbr and firmAgeAtDeal) 


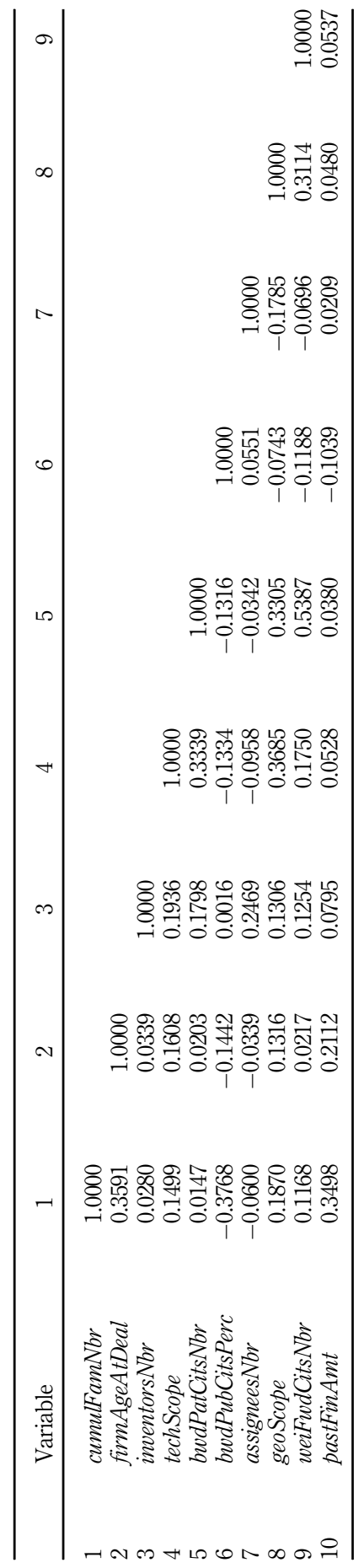

How VCs evaluate YIC patent portfolios

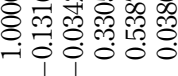

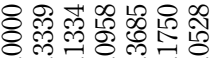
- 00000

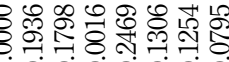
ช

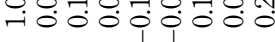

8ㄱㅇㅇㅝ 400000000 


\section{IJEBR 26,4}

\begin{tabular}{|c|c|c|c|c|}
\hline Regressor & Model 1 & Model 2 & Model 3 & Model 4 \\
\hline famDum & $\begin{array}{l}0.171^{* *} \\
(0.071)\end{array}$ & & & \\
\hline cumulFamNbr & & $\begin{array}{l}0.106 \text { *** } \\
(0.043)\end{array}$ & $\begin{array}{c}0.091 \\
(0.072)\end{array}$ & $\begin{array}{c}0.084 \\
(0.073)\end{array}$ \\
\hline \multicolumn{2}{|l|}{ Complexity measures } & & $\begin{array}{r}-0.013 \\
(0.043)\end{array}$ & $\begin{array}{r}-0.015 \\
(0.043)\end{array}$ \\
\hline techScope & & & $\begin{array}{c}-0.038 \\
(0.073)\end{array}$ & $\begin{array}{c}-0.034 \\
(0.073)\end{array}$ \\
\hline bwdPatCitsNbr & & & $\begin{array}{c}0.001 \\
(0.003)\end{array}$ & $\begin{array}{c}-0.001 \\
(0.004)\end{array}$ \\
\hline bwdPubCitsPerc & & & $\begin{array}{c}-0.262 \\
(0.397)\end{array}$ & $\begin{array}{c}-0.243 \\
(0.399)\end{array}$ \\
\hline $\begin{array}{l}\text { Quality measures } \\
\text { assignees } \mathrm{Nbr}\end{array}$ & & & $\begin{array}{l}0.179 \text { ** } \\
(0.083)\end{array}$ & $\begin{array}{l}0.181^{* *} \\
(0.082)\end{array}$ \\
\hline geoScope & & & $\begin{array}{c}0.039 \\
(0.024)\end{array}$ & $\begin{array}{c}0.034 \\
(0.024)\end{array}$ \\
\hline weiFwdCitsNbr & & & & $\begin{array}{l}0.086^{*} \\
(0.052)\end{array}$ \\
\hline \multicolumn{5}{|l|}{ Control variables } \\
\hline & $(0.003)$ & $(0.003)$ & $(0.002)$ & $(0.002)$ \\
\hline firmAgeAtDeal & $\begin{array}{c}0.011 \\
(0.012)\end{array}$ & $\begin{array}{l}0.009 \\
(0.012)\end{array}$ & $\begin{array}{c}-0.015 \\
(0.017)\end{array}$ & $\begin{array}{c}-0.015 \\
(0.017)\end{array}$ \\
\hline Time, sector, geo dummies & Yes & Yes & Yes & Yes \\
\hline Round dummies & Yes & Yes & Yes & Yes \\
\hline Constant & $\begin{array}{l}-1.283 \\
(27.055)\end{array}$ & $\begin{array}{l}-3.863 \\
(26.903)\end{array}$ & $\begin{array}{c}60.641 * \\
(36.383)\end{array}$ & $\begin{array}{c}52.262 \\
(36.520)\end{array}$ \\
\hline Observations & 1,988 & 1,988 & 726 & 726 \\
\hline$R$-squared & 0.485 & 0.486 & 0.421 & 0.423 \\
\hline Adjusted $R$-squared & 0.478 & 0.479 & 0.396 & 0.397 \\
\hline
\end{tabular}

Table 6.

Regression results, baseline models
Note(s): The dependent variable is the logarithm of the financed amount. Robust standard errors are shown in parentheses. Models 1 and 2 are tested on the full sample of companies. Models 3 and 4 are tested on the subsample of companies with at least one patent. The significance levels are represented by $* * *$ as $1 \%, * *$ as $5 \%$, and $*$ as $10 \%$

patent portfolios among the covariates. It is worth noting that nonpatenting companies have been dropped from the sample in Models 3 and 4 [13].

The analysis on the full sample confirms that firms with at least one patent are on average associated with a higher amount of $\mathrm{VC}$, which is also positively related to the size of the patent portfolio of a firm. The finding corroborates the positive link between the patenting activities and the VC financing highlighted by the extant literature. Going beyond the mere number of patents, the results show that no measure of complexity affects the amount of VC significantly, while two indicators of the quality of the patent portfolios - the number of assignees and forward citations - are positively and significantly associated with VC funding. Although still having a positive coefficient in Models 3 and 4, the cumulated portfolio size is no longer significantly related to the VC amount. In the sub-sample of companies with at least one patent, some technological characteristics on average seem to be more frequently associated with more valuable financing rounds than the patent portfolio 


\begin{tabular}{|c|c|c|c|c|c|c|c|}
\hline Regressor & $\begin{array}{l}\text { Model } 1 \\
\quad \text { Low a1 }\end{array}$ & $\begin{array}{l}\text { Model } 2 \\
\text { propriability }\end{array}$ & $\begin{array}{l}\text { Model } 3 \\
\text { sectors }\end{array}$ & $\begin{array}{l}\text { Model } 4 \\
\text { High a }\end{array}$ & $\begin{array}{l}\text { Model } 5 \\
\text { ppropriability }\end{array}$ & $\begin{array}{l}\text { Model } 6 \\
\text { sectors }\end{array}$ & $\begin{array}{r}\text { How VCs } \\
\text { evaluate YIC }\end{array}$ \\
\hline famDum & $\begin{array}{c}0.085 \\
(0.081)\end{array}$ & & & $\begin{array}{l}0.395^{* * * *} \\
(0.136)\end{array}$ & & & portfolios \\
\hline cumulFamNbr & & $\begin{array}{c}0.034 \\
(0.054)\end{array}$ & $\begin{array}{r}-0.063 \\
(0.100)\end{array}$ & & $\begin{array}{l}0.249 * * * \\
(0.059)\end{array}$ & $\begin{array}{l}0.258^{* * * *} \\
(0.098)\end{array}$ & \\
\hline \multirow{2}{*}{$\begin{array}{l}\text { Complexity measures } \\
\text { inventors Nbr }\end{array}$} & & & & & & & 709 \\
\hline & & & $\begin{array}{c}-0.001 \\
(0.044)\end{array}$ & & & $\begin{array}{r}-0.058 \\
(0.064)\end{array}$ & \\
\hline techScope & & & $\begin{array}{c}0.094 \\
(0.094)\end{array}$ & & & $\begin{array}{r}-0.077 \\
(0.083)\end{array}$ & \\
\hline bwdPatCitNbr & & & $\begin{array}{r}-0.007 \\
(0.009)\end{array}$ & & & $\begin{array}{l}0.000 \\
(0.004)\end{array}$ & \\
\hline bwdPubCitsPerc & & & $\begin{array}{c}-0.287 \\
(0.445)\end{array}$ & & & $\begin{array}{r}-0.549 \\
(0.916)\end{array}$ & \\
\hline $\begin{array}{l}\text { Quality measures } \\
\text { assignees Nbr }\end{array}$ & & & $\begin{array}{l}0.143^{* *} \\
(0.072)\end{array}$ & & & $\begin{array}{c}0.295 \\
(0.224)\end{array}$ & \\
\hline geoScope & & & $\begin{array}{l}0.041 \\
(0.035)\end{array}$ & & & $\begin{array}{c}0.052 \\
(0.032)\end{array}$ & \\
\hline weiFwdCitsNbr & & & $\begin{array}{c}0.116 \\
(0.076)\end{array}$ & & & $\begin{array}{c}0.052 \\
(0.116)\end{array}$ & \\
\hline \\
\hline $\begin{array}{l}\text { Control variables } \\
\text { pastFinAmt }\end{array}$ & $\begin{array}{l}0.009 * * \\
(0.004)\end{array}$ & $\begin{array}{l}0.009 * * \\
(0.004)\end{array}$ & $\begin{array}{l}0.014^{* * * *} \\
(0.002)\end{array}$ & $\begin{array}{l}0.010^{* * * *} \\
(0.003)\end{array}$ & $\begin{array}{l}0.008^{* * * *} \\
(0.003)\end{array}$ & $\begin{array}{l}0.007 * * * * \\
(0.002)\end{array}$ & \\
\hline firmAgeAtDeal & $\begin{array}{l}0.023^{*} \\
(0.014)\end{array}$ & $\begin{array}{l}0.024^{*} \\
(0.014)\end{array}$ & $\begin{array}{l}0.020 \\
(0.024)\end{array}$ & $\begin{array}{c}-0.021 \\
(0.022)\end{array}$ & $\begin{array}{c}-0.029 \\
(0.021)\end{array}$ & $\begin{array}{l}-0.051 * * \\
(0.023)\end{array}$ & \\
\hline Time, sector, geo dummies & Yes & Yes & Yes & Yes & Yes & Yes & \\
\hline Round dummies & Yes & Yes & Yes & Yes & Yes & Yes & \\
\hline Constant & $\begin{array}{r}-21.095 \\
(31.047)\end{array}$ & $\begin{array}{r}-19.569 \\
(31.615)\end{array}$ & $\begin{array}{l}12.934 \\
(50.430)\end{array}$ & $\begin{array}{c}61.928 \\
(54.460)\end{array}$ & $\begin{array}{l}50.906 \\
(51.727)\end{array}$ & $\begin{array}{c}93.973 \\
(60.221)\end{array}$ & \\
\hline Observations & 1,988 & 1,988 & 355 & 490 & 490 & 371 & \\
\hline$R$-squared & 0.485 & 0.486 & 0.501 & 0.374 & 0.394 & 0.388 & \\
\hline Adjusted $R$-squared & 0.478 & 0.479 & 0.463 & 0.352 & 0.372 & 0.347 & Table 7. \\
\hline \multicolumn{7}{|c|}{$\begin{array}{l}\text { Note(s): The dependent variable is the logarithm of the financed amount. Robust standard errors are shown in } \\
\text { parentheses. Models from } 1 \text { to } 3 \text { and from } 4 \text { to } 6 \text { are tested on the low and high appropriability sectors, } \\
\text { respectively. Models } 3 \text { and } 6 \text { are tested on the sub-sample of companies holding at least one patent. The } \\
\text { significance levels are represented by } * * * \text { as } 1 \% \text {, ** as } 5 \% \text {, and * as } 10 \%\end{array}$} & $\begin{array}{r}\text { Regression results, } \\
\text { subsamples of sectors } \\
\text { with high and low } \\
\text { patent intensity }\end{array}$ \\
\hline
\end{tabular}

size. Table 6 shows that technological complexity does not report any significant statistical association along all dimensions, while the findings support the presence of a positive relationship between VCs and firms that own inventions developed through collaborative networks and which are better from a technical point of view.

In order to disentangle the differential role of the patenting activities into different sectors, the full sample was also split into two subgroups, according to the IP regime that characterizes the corresponding sector (see Table 7 for the regression results, where Models 1 to 3 and 4 to 6 are tested on the low and high appropriability sectors, respectively). The analysis on the subsample of firms in sectors characterized by low patent intensity reveals a weaker correlation between $\mathrm{VC}$ funding and patenting: neither the presence of a patent nor the portfolio size is associated with an increase in the financed amount. The measures of complexity are again not significantly related to the amount of VC. As far as 
IJEBR

26,4

710

technological quality is concerned, the presence of collaborations is instead positively related to VC financing. Patents are not valuable per se in sectors characterized by weak IP regimes, hence the signaling effect might be lost. However, a positive relationship with the amount of $\mathrm{VC}$ funding has been found when the protected technology is the result of a collaborative effort involving other parties. On the contrary, the quantity indicators (e.g. dummy and portfolio size) are positively correlated in the subsample of industries with high patent intensity, while quality proxies are not significant. In sectors characterized by strong IP regimes, the patenting activity appears as a positive signal for VC investors, beyond the qualitative aspects of the patent portfolio. No significant result has been found for the proxies of complexity.

We performed several robustness checks. First, we replicated the econometric analysis by testing Tobit models with left censoring limit, since the $\mathrm{VC}$ amount can only assume positive values. The results are coherent with the regression (the output for the baseline models are shown in Table A1 of the Appendix). Second, we performed a sensitivity test on the threshold level for the models that distinguishes subsamples with high and low patent intensity. The results for the subsamples in which the sectors near the threshold have been excluded [14] are shown in Table A2 of the Appendix: in the subsample of low patent intensity sectors, the number of assignees is still positive but no longer significant. Third, we tested additional sets of models on subsamples of data that exclude the most represented country and industries, respectively (Table A3 of the Appendix). The results are in line with those of the baseline specification: both the size of the patent portfolio and the same complexity and quality indicators are significantly associated to VC funding, with a few exceptions.

Table 8 presents the results for the different rounds of $\mathrm{VC}$ investments. The findings reveal that the presence and the size of a patent portfolio at the seed stage are not significant, while the geographical scope (i.e. the number of countries of extension) and the basicness of the inventions are positively and negatively related, respectively. Similar results are found for the quantitative aspects of the patenting activities from the analysis of the A-series rounds: the portfolio size is not significant. The number of assignees, which proxies for quality in terms of R\&D collaborations and the number of IPC subclasses, which represents the technological scope, are positive and significant. It thus seems that, in the early stages, on average the financed amount is not related to the portfolio size, while other aspects of technological complexity and quality matter more: as far as the seed stage is concerned, VCs provide on average more financing to companies that hold inventions that are closer to the commercialization stage, which have a wider market potential; for the A-series, a higher financed amount is associated with redeployable technologies and developed with other R\&D partners. In the later stages, the portfolio size, as well as other patent characteristics, is statistically significantly related to the received VC amount, thereby supporting the presence of a signaling effect of patents. All the quality metrics (i.e. the number of assignees, the geographical scope and the technical merit) are found to be positively and significantly correlated to the amount of VC financing. Furthermore, two technological complexity variables - the number of backward citations and the number of IPC codes - are negatively related to the financed amount, thus suggesting a preference for novel and more focused inventions. When the $\mathrm{VC}$ amount is larger, patents are considered assets that may help reduce the financial risk associated with information asymmetries. Moreover, the patent portfolio can provide useful information on the quality, technical merit and novelty of inventions from YICs, and thus contribute toward alleviating the technical and market risks associated with information asymmetries. A comparison of the results across the different stages indicates that the presence of the signaling effect is stronger for the later stages when the amounts are larger. 


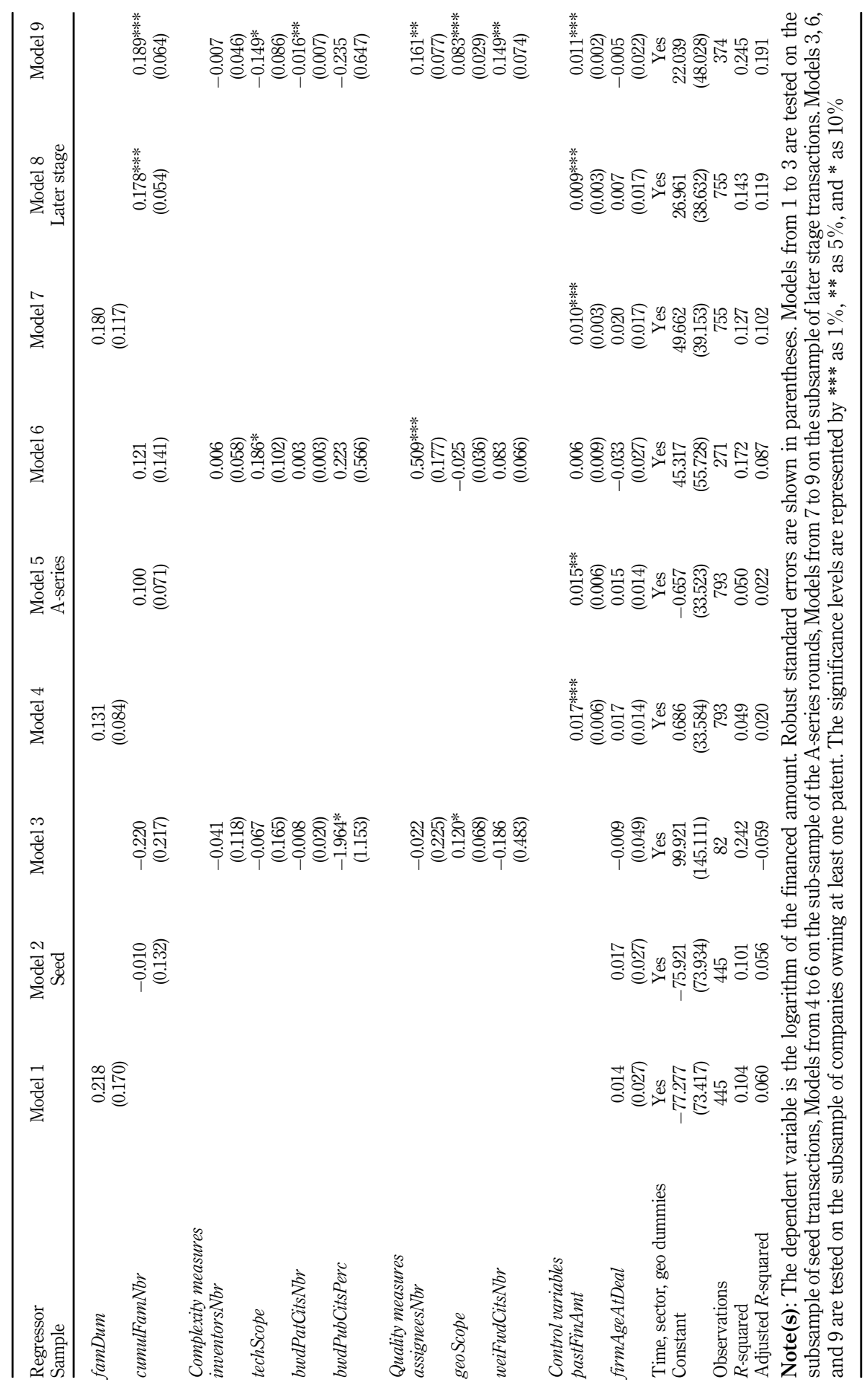

How VCs evaluate YIC patent portfolios

711

Table 8. Regression results, subsamples of VC financing rounds 
IJEBR

26,4

712

\section{Discussion and conclusion}

This paper has examined the importance given by VC firms to different characteristics of a YIC patent portfolio and whether the signaling effects of patents on VC financing varies across different industrial sectors and over different rounds of investments. The empirical analysis has focused on a large sample of European YICs over the years between 2010 and 2014.

The results confirm the positive signaling effect of patents belonging to a technologybased company on VC. However, it appears not only to be correlated to the portfolio size, but also to the characteristics of the patented inventions. Furthermore, the signaling effect of patenting and the related VC premium vary across industries, in terms of patent intensity, and across financing stages.

When the association between patenting activities and VC financing across different sectors were disentangled, the findings revealed that although the number of patents is a positive signal for VCs in sectors with strong IP regimes, the same does not apply for those industrial fields that are characterized by weak IP regimes, where only one of the qualitative metrics, collaborativeness (i.e. the number of assignees), seems to have a signaling power. Unsurprisingly, patented technologies originating from R\&D alliances are valued by VC investors and are positively related to the amount of financing.

Significant differences across the rounds of VC investments have also been found. The financed VC amount was not found to be correlated to the patent portfolio size when early stages (i.e. the seed and A-round stages), which are characterized by high risks but lower levels of investment, were considered. The evidence is consistent with some previous studies (Mann, 2004; Hsu, 2004; Mann and Sager, 2007) according to which many decisions of investors are little or not driven at all by the presence of patents in their initial investment. On the contrary, the evidence that, at later stages, the financed amount is associated with the presence of larger patent portfolios confirms the previous findings that VC investors could have a higher interest in patents when companies have started to generate revenues from technologies that would require protection from imitation (Mann, 2004).

Seed investments are, on average, larger when the protected technology is further from basic science and thus closer to industrialization, and with a wider potential international market. A-series rounds are more favorable for those firms which have inventions with a wider technological scope (more potential fields of application) and those are developed with partners. Collaborations also seem to matter for firms that are involved in subsequent stages of investment. On the contrary, at later stages, when larger amounts of capital are involved, YICs with larger and higher quality patent portfolios on average seemed to receive a VC funding premium. As far as complexity measures are concerned, a narrow technological scope is awarded at later stages of financing: companies are required to have defined their market and the technological areas of development. Furthermore, patents characterized by higher novelty that build on fewer existing technologies are important drivers of radical innovation and seem to attract larger amounts of VC funding in later financing rounds. Because the number of jurisdictions in which the patent protection is sought proxies the quality of the underlying invention and the early internationalization of the patent assignee, its positive association with the amount of $\mathrm{VC}$ financing at both seed and later financing stages appears to be consistent with the expectations laid out in the research framework.

The results of this analysis have important implications from several perspectives. As far as firms that try to signal their value at the beginning of their activities in sectors with weak IP regimes are concerned, the presence of patented inventions is not associated with attracting more VC funding, while collaborativeness might reduce risks in the eye of the investor and bring in more financing. In industries in which patent intensity is higher, the patent portfolio size matters more than the quality to create a sufficiently high fence in order to protect the technology. 
Even though patenting in quantitative terms does not seem to be conducive to larger investments at the earlier stages, when complementary elements may win VC favors (e.g. team experience, social capital), since the findings suggest that the positive associations between patenting activities and VC financing are more significant at the later stages, the authors argue that managers should plan and adopt their patenting strategy in advance to reap the benefits of patent filings and then collect the premium at later VC stages.

Focusing on the perspective of the investors, the patenting activity does not seem to be meaningful per se in the seed stages, where information asymmetries are higher: a simple patent filing might not be sufficient to be considered a credible signal that can be interpreted as risk mitigation. The financed amount in seed stages is higher if the protected inventions have fewer scientific citations or, in other words, greater feasibility, and a broader geographical scope, proxy of quality and market potential, and representing a higher commitment of the company (patent protection in more than one country includes patent fees, the cost of the attorneys and translation services, which can easily reach 20-30 thousand euros, a non-negligible sum for a YIC). Similar results have been found for the A-series, where $\mathrm{VC}$ investors seem to award a financing premium when the protected technology has a wider range of possible applications and results from research collaborations, both of which are elements of risk mitigation. On the contrary, at the later stages, when information asymmetries are reduced, but the amounts that are invested are higher, both the size and the characteristics of a portfolio seem relevant signals to VC investors. Investors seem to prefer novel, more technologically focused, and feasible inventions. From a wider perspective, the results support the argument of the pro-competitive role of patents, which favors the entry of start-ups through VC financing under a strong IP regime.

The limitations of this study are related to data availability. Although empirical associations have been investigated, no causal effects can be ascertained in this framework. The authors acknowledge that the proposed empirical settings does not allow the direct effects of the signaling role that patent rights may exert on mitigating information asymmetries between YICs and VC investors to be disentangled from the gains in economic value related to the exploitation and strategic use of patents by the financed company. The analysis has focused on a sample of firms that received VC funding, while future research could try to overcome the limit of the potential selection effect by building a dataset that includes VC-funded firms and comparable companies that have not been funded by VCs. Furthermore, a number of potential drivers of the financed amounts, such as variables related to the founder or to the management team, have not been considered in this paper. Finally, future research could focus on the characteristics of VCs to understand whether the signaling effect is more likely to be observed in the presence of syndicates, international funds, or specific types of investors.

\section{Notes}

1. It should be noted that some exceptions can be identified in the literature. A few authors did not find any significant effect, while others discovered negative effects of patent rights on VC financing (Deeds et al., 1997; Knockaert et al., 2010; Stuart et al., 1999).

2. It is worth noting that previous works (Popov and Roosenboom, 2012; Bertoni and Tykvová, 2015) dealing with the relationship between innovation activities and VC financing have a similar geographical coverage. Nevertheless, the suggested papers are different from the present work along other dimensions. First, they are focused on the inverse relationship. Bertoni and Tykvová (2015) study the effect of funding provided by different types of VC investors on innovation activities in the context of a single industrial sector, i.e. biotechnology. The work by Popov and Roosenboom (2012) explores the impact of VC financing on patented inventions. Moreover, both the sectoral composition of the samples (i.e., food, textile, chemical, metal products, machinery and equipment, motor vehicles) and the analyzed years (i.e., from 1991 to 2005) are different from those in our dataset. Also, these contributions only use patent filings at the USPTO and do not consider a

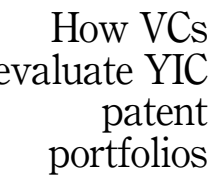

713 
IJEBR

26,4 number of characteristics at the patent family level (e.g., the international coverage of the legal protection, the number of received citations).

3. However, Meyer (2000) suggests caution when considering non-patent citations because they might have been added by the applicant in an attempt to increase the breadth of patent coverage or added by the examiner as standard practice for certain fields.

4. Go4Venture was a company of corporate finance advisors (go4venture.com).

5. FinSMEs publishes information on deals and transactions made by all kinds of investors from a number of countries all over the world (finsmes.com). Crunchbase grants access to their dataset for research purposes (crunchbase.com).

6. The other resources used to complete the missing data and check the collected information are owler.com, techcrunch.com, businessweek.com, and the official websites of the selected companies.

7. All the $\mathrm{VC}$ rounds that had no clear specification or which were associated with business angels and private equity have been excluded.

8. The amount was calculated from the reports available on Invest Europe/EVCA website (investeurope.eu, last accessed in November 2019).

9. As an additional control, we checked a random sample of 50 companies (representing $4.6 \%$ of the examined firms) for which we identified the founders and searched for whether patents had only been assigned to the founders (i.e., the patent had not been assigned to a company). We found the start-up name (either the original or an updated one) in the assignee field of 97 patents (54.8\%); 3 patents are assigned to the company from which the examined start-up had spun off; 1 patent is held by the buyer of the technology developed by the start-up; we found the names of companies operating in the same field as the start-up, other firms, or universities in the assignee field of 15 patents. Out of 177 patents, $20(11.3 \%)$ are assigned exclusively to inventors: only 5 patents (corresponding to $2.8 \%$ of the overall examined portfolios) belong to one of the start-up founders (however, 2 of them are part of a patent family in which at least one of the other family members is assigned to the start-up).

10. Among the several definitions of patent family (see Martínez, 2010), the INPADOC patent family is here employed to study the cumulativeness of inventions. More information can be found on the EPO website (epo.org/searching-for-patents/ helpful-resources/first-time-here/patent-families/ inpadoc.html, last accessed in May 2017).

11. Software, Mobile is near the threshold value, with its 2.3 patented inventions per firm. It was also included in the low patent intensity group on the basis of issues concerning the patentability of software, which are generally stricter in EU than in the US.

12. The sectors are classified in a number of previous studies on the basis of survey data concerning all the possible means of appropriability (e.g., patents, secrecy, lead time, trademarks, complementary assets, etc.) and with different focuses in terms of geographical scope and firm size (see, for instance, Cohen et al., 2000). Unfortunately, such classifications are not up-to-date and do not cover all the fields available in the collected sample of firms (the focus in the extant literature is on manufacturing). The proposed approach has been able to cope with the above-mentioned limitations by relying on the identification of patent intensity at the sector level. Patent intensity is here computed as the average number of patents per firm by collecting all the patents of European companies for each NACE code (the data has been gathered from the ORBIS database). An effort has been made to match the categories used in the paper with the categories employed in the surveybased works of Cohen et al. (2000) and to those based on the NACE classification (Colombelli et al., 2019). Such a process is not straightforward because of multiple concordances and different categorization approaches.

13. As this procedure may raise some concerns about selection bias, further regressions on the full sample of companies have been also run by setting the patent-related variables to zero for nonpatenting firms. This further check confirmed the robustness of the results. 
14. The sector Education has also been excluded since it has been associated, in the extant literature, with higher levels of patent intensity (Colombelli et al., 2019).

\section{References}

Agostini, L., Caviggioli, F., Filippini, R. and Nosella, A. (2015), "Does patenting influence SME sales performance? A quantity and quality analysis of patents in Northern Italy", European Journal of Innovation Management, Vol. 18 No. 2, pp. 238-257.

Arundel, A. (2001), "The relative effectiveness of patents and secrecy for appropriation", Research Policy, Vol. 30 No. 4, pp. 611-624.

Atherton, A. (2012), "Cases of start-up financing: an analysis of new venture capitalisation structures and patterns", International Journal of Entrepreneurial Behavior and Research, Vol. 18 No. 1, pp. $28-47$.

Audretsch, D.B., Bönte, W. and Mahagaonkar, P. (2012), "Financial signaling by innovative nascent ventures: the relevance of patents and prototypes", Research Policy, Vol. 41 No. 8, pp. 1407-1421.

Baum, J.A.C. and Silverman, B.S. (2004), "Picking winners or building them? Alliance, intellectual, and human capital as selection criteria in venture financing and performance of biotechnology startups", Journal of Business Venturing, Vol. 19 No. 3, pp. 411-436.

Bergset, L. (2018), "Green start-up finance - where do particular challenges lie?”, International Journal of Entrepreneurial Behavior and Research, Vol. 24 No. 2, pp. 451-575.

Bertoni, F. and Tykvová, T. (2015), "Does governmental venture capital spur invention and innovation? Evidence from young European biotech companies", Research Policy, Vol. 44 No. 4, pp. 925-935.

Bloodgood, J.M. (2006), "Venture adolescence: internationalization and performance implications of maturation", International Journal of Entrepreneurial Behavior and Research, Vol. 12 No. 2, pp. $67-85$.

Busenitz, L.W., Fiet, J.O. and Moesel, D.D. (2005), "Signaling in venture capitalist - new venture team funding decisions: does it indicate long-term venture outcomes?", Entrepreneurship: Theory and Practice, Vol. 29 No. 1, pp. 1-12.

Caviggioli, F. and Ughetto, E. (2016), "Buyers in the patent auction market: opening the black box of patent acquisitions by non-practicing entities", Technological Forecasting and Social Change, Vol. 104, pp. 122-132.

Caviggioli, F., De Marco, A., Scellato, G. and Ughetto, E. (2017), "Corporate strategies for technology acquisition: evidence from patent transactions”, Management Decision, Vol. 55 No. 6, pp. 1163-1181.

Ciaramella, L., Martínez, C. and Ménière, Y. (2017), "Tracking patent transfers in different European countries: methods and a first application to medical technologies", Scientometrics, Vol. 112 No. 2, pp. 817-850.

Cockburn, I.M. and MacGarvie, M.J. (2009), "Patents, thickets and the financing of early-stage firms: evidence from the software industry", Journal of Economics and Management Strategy, Vol. 18 No. 3, pp. 729-773.

Cohen, W.M., Nelson, R.R. and Walsh, J.P. (2000), "Protecting their intellectual assets: appropriability conditions and why US manufacturing firms patent (or not)", Technical Report, National Bureau of Economic Research.

Colombelli, A. (2015), "Top management team characteristics and firm growth: evidence from a sample of listed companies”, International Journal of Entrepreneurial Behavior and Research, Vol. 21 No. 1, pp. 107-127.

Colombelli, A., Grilli, L., Minola, T. and Mrkajic, B. (2019), "To what extent do young innovative companies take advantage of policy support to enact innovation appropriation mechanisms?", Research Policy, (in press).
How VCs
evaluate YIC
patent
portfolios

715 
IJEBR

26,4

Colombo, M.G., Rossi-Lamastra, C. and Wright, M. (2018), "Accelerators: insights for a research agenda”, in Wright, M. (Ed.), Accelerators: Successful Venture Creation and Growth, Edward Elgar Publishing, Cheltenham.

Conti, A., Thursby, M. and Rothaermel, F.T. (2013), "Show me the right stuff: signals for high-tech startups", Journal of Economics and Management Strategy, Vol. 22 No. 2, pp. 341-364.

De Marco, A., Scellato, G., Ughetto, E. and Caviggioli, F. (2017), "Global markets for technology: evidence from patent transactions”, Research Policy, Vol. 46 No. 9, pp. 1644-1654.

Deeds, D.L., Decarolis, D. and Coombs, J.E. (1997), "The impact of firm-specific capabilities on the amount of capital raised in an initial public offering: evidence from the biotechnology industry", Journal of Business Venturing, Vol. 12 No. 1, pp. 31-46.

Dushnitsky, G. and Lenox, M.J. (2005), "When do incumbents learn from entrepreneurial ventures? Corporate venture capital and investing firm innovation rates", Research Policy, Vol. 34 No. 5, pp. 615-639.

Engel, D. and Keilbach, M. (2007), "Firm-level implications of early stage venture capital investment an empirical investigation", Journal of Empirical Finance, Vol. 14 No. 2, pp. 150-167.

Figueroa, N. and Serrano, C.J. (2019), "Patent trading flows of small and large firms", Research Policy, Vol. 48 No. 7, pp. 1601-1616.

Flynn, D. and Forman, A.M. (2001), "Life cycles of new venture organizations: different factors affecting performance", Journal of Developmental Entrepreneurship, Vol. 6 No. 1, p. 41.

Fried, V.H. and Hisrich, R.D. (1994), "Toward a model of venture capital investment decision making", Financial Management, Vol. 23 No. 3, pp. 28-38.

Gans, J.S. (2002), "When does start-up innovation spur the gale of creative destruction?", The RAND Journal of Economics, Vol. 33 No. 4, pp. 571-586.

Giuri, P., Mariani, M., Brusoni, S., Crespi, G., Francoz, D., Gambardella, A., Garcia-Fontes, W., Geuna, A., Gonzales, R., Harhoff, D., Hoisl, K., Le Bas, C., Luzzi, A., Magazzini, L., Nesta, L., Nomaler, Ö, Palomeras, N., Patel, P., Romanelli, M. and Verspagen, B. (2007), "Inventors and invention processes in Europe: results from the PatVal-EU survey", Research Policy, Vol. 36 No. 8, pp. 1107-1127.

Graham, S.J.H., Merges, R.P., Samuelson, P. and Sichelman, T. (2009), "High technology entrepreneurs and the patent system: results of the 2008 Berkeley patent survey", Berkeley Technology Law Journal Vol. 24 No. 4, pp. 1255-1327.

Gredel, D., Kramer, M. and Bend, B. (2012), "Patent-based investment funds as innovation intermediaries for SMEs: in-depth analysis of reciprocal interactions, motives and fallacies", Technovation, Vol. 32 Nos 9-10, pp. 536-549.

Guellec, D. and van Pottelsberghe de la Potterie, B. (2000), "Applications, grants and the value of patent”, Economics Letters, Vol. 69 No. 1, pp. 109-114.

Hall, B., Helmers, C., Rogers, M. and Sena, V. (2014), "The choice between formal and informal intellectual property: a review", Journal of Economic Literature, Vol. 52 No. 2, pp. 375-423.

Harhoff, D., Narin, F., Scherer, F.M. and Vopel, K. (1999), "Citation frequency and the value of patented inventions", The Review of Economics and Statistics, Vol. 81 No. 3, pp. 511-515.

Häussler, C., Harhoff, D. and Mueller, E. (2014), "How patenting informs VC investors - the case of biotechnology", Research Policy, Vol. 43 No. 8, pp. 1286-1298.

Heeley, M.B., Matusik, S.F. and Jain, N. (2007), "Innovation, appropriability, and the underpricing of initial public offerings", Academy of Management Journal, Vol. 50 No. 1, pp. 209-225.

Helmers, C. and Rogers, M. (2011), "Does patenting help high-tech start-ups?”, Research Policy, Vol. 40 No. 7, pp. 1016-1027.

Higgins, M.C. and Gulati, R. (2006), "Stacking the deck: the effects of top management backgrounds on investor decisions", Strategic Management Journal, Vol. 27 No. 1, pp. 1-25. 
Hoenen, S., Kolympiris, C., Schoenmakers, W. and Kalaitzandonakes, N. (2014), "The diminishing signaling value of patents between early rounds of venture capital financing”, Research Policy, Vol. 43 No. 6, pp. 956-989.

Hoenig, D. and Henkel, J. (2015), "Quality signals? The role of patents, alliances, and team experience in venture capital financing", Research Policy, Vol. 44 No. 5, pp. 1049-1064.

Hsu, D.H. (2004), "What do entrepreneurs pay for venture capital affiliation?", The Journal of Finance, Vol. 59 No. 4, pp. 1805-1844.

Hsu, D.H. (2007), "Experienced entrepreneurial founders, organizational capital, and venture capital funding”, Research Policy, Vol. 36 No. 5, pp. 722-741.

Hsu, D.H. and Ziedonis, R.H. (2013), "Resources as dual sources of advantage: implications for valuing entrepreneurial-firm patents”, Strategic Management Journal, Vol. 34 No. 7, pp. 761-781.

Janney, J.J. and Folta, T.B. (2003), "Signaling through private equity placements and its impact on the valuation of biotechnology firms", Journal of Business Venturing, Vol. 18 No. 3, pp. 361-380.

Jeng, L.A. and Wells, P.C. (2000), "The determinants of venture capital funding: evidence across countries", Journal of Corporate Finance, Vol. 6 No. 3, pp. 241-289.

Knockaert, M., Clarysse, B. and Wright, M. (2010), "The extent and nature of heterogeneity of venture capital selection behaviour in new technology-based firms", R\&D Management, Vol. 40 No. 4, pp. 357-371.

Kolympiris, C., Hoenen, S. and Kalaitzandonakes, N. (2017), "Geographic distance between venture capitalists and target firms and the value of quality signals", Industrial and Corporate Change, Vol. 27 No. 1, pp. 189-220.

Lahr, H. and Mina, A. (2016), "Venture capital investments and the technological performance of portfolio firms", Research Policy, Vol. 45 No. 1, pp. 303-318.

Lam, W. (2010), "Funding gap, what funding gap? Financial bootstrapping: supply, demand and creation of entrepreneurial finance", International Journal of Entrepreneurial Behavior and Research, Vol. 16 No. 4, pp. 268-295.

Lemley, M.A. (2000), "Rational ignorance at the patent office", Northwestern University Law Review, Vol. 95, p. 1495.

Lerner, J. (1994), "The importance of patent scope: an empirical analysis", The RAND Journal of Economics Vol. 25 No. 2, pp. 319-333.

Lev, B. (2000), Intangibles: Management, Measurement, and Reporting, Brookings Institution Press, Washington.

Long, C. (2002), "Patent signals", The University of Chicago Law Review, Vol. 69 No. 2, pp. 625-679.

Macht, S.A. and Robinson, J. (2009), "Do business angels benefit their investee companies?", International Journal of Entrepreneurial Behavior and Research, Vol. 15 No. 2, pp. 187-208.

Mann, R.J. (2004), "Do patents facilitate financing in the software industry", Texas Law Review, Vol. 83 No. 4, pp. 961-1030.

Mann, R.J. and Sager, T.W. (2007), "Patents, venture capital, and software start-ups", Research Policy, Vol. 36 No. 2, pp. 193-208.

Martínez, C. (2010), "Patent families: when do different definitions really matter?", Scientometrics, Vol. 86 No. 1, pp. 39-63.

Meyer, M. (2000), "What is special about patent citations? Differences between scientific and patent citations", Scientometrics, Vol. 49 No. 1, pp. 93-123.

Munari, F. and Toschi, L. (2015), "Do patents affect VC financing? Empirical evidence from the nanotechnology sector", The International Entrepreneurship and Management Journal, Vol. 11 No. 3, pp. 623-644.

Nadeau, P. (2010), "Venture capital investment selection: do patents attract investors?", Strategic Change, Vol. 19 Nos 7-8, pp. 325-342.
How VCs
evaluate YIC
patent
portfolios 
IJEBR

26,4

Pakes, A. and Griliches, Z. (1980), "Patents and R\&D at the firm level: a first report", Economics letters, Vol. 5 No. 4, pp. 377-381.

Pandey, I.M. and Jang, A. (1996), "Venture capital for financing technology in Taiwan", Technovation, Vol. 16 No. 9, pp. 499-523.

Petty, J.S. and Gruber, M. (2011), "In pursuit of the real deal: a longitudinal study of VC decision making", Journal of Business Venturing, Vol. 26 No. 2, pp. 172-188.

Popov, A. and Roosenboom, P. (2012), "Venture capital and patented innovation: evidence from Europe", Economic Policy, Vol. 27 No. 71, pp. 447-482.

Reitzig, M. (2003), "What determines patent value? Insights from the semiconductor industry", Research Policy Vol. 32 No. 1, pp. 13-26.

Santarelli, E. and Lotti, F. (2008), "Innovative output, productivity and profitability. A test comparing USPTO and EPO data", Industry and Innovation Vol. 15 No. 4, pp. 393-409.

Scherer, F.M. and Harhoff, D. (2000), "Technology policy for a world of skew-distributed outcomes", Research Policy Vol. 29 Nos 4-5, pp. 559-566.

Schneider, C. and Veugelers, R. (2010), "On young highly innovative companies: why they matter and how (not) to policy support them", Industrial and Corporate Change Vol. 19 No. 4, pp. 969-1007.

Serrano, C.J. (2010), "The dynamics of the transfer and renewal of patents", The RAND Journal of Economics, Vol. 41 No. 4, pp. 686-708.

Smith, J.A. and Cordina, R. (2015), "Patenting and the early-stage high-technology investor: evidence from the field", R\&D Management, Vol. 45 No. 5, pp. 589-605.

Söderblom, A., Samuelsson, M., Wiklund, J. and Sandberg, R. (2015), "Inside the black box of outcome additionality: effects of early-stage government subsidies on resource accumulation and new venture performance”, Research Policy, Vol. 44 No. 8, pp. 1501-1512.

Spence, M. (1973), "Job market signaling”, The Quarterly Journal of Economics, Vol. 87 No. 3, pp. $355-374$.

Spence, M. (2002), "Signaling in retrospect and the informational structure of markets", The American Economic Review, Vol. 92 No. 3, pp. 434-459.

Stuart, T.E., Hoang, H. and Hybels, R.C. (1999), "Interorganizational endorsements and the performance of entrepreneurial ventures", Administrative Science Quarterly, Vol. 44 No. 2, pp. 315-349.

Tietze, F. (2012), Technology Market Transactions: Auctions, Intermediaries and Innovation, Edward Elgar Publishing, Cheltenham.

Trajtenberg, M. (1990), “A penny for your quotes: patent citations and the value of innovations", The RAND Journal of Economics, Vol. 21 No. 1, pp. 172-187.

van Zeebroeck, N. and van Pottelsberghe, B. (2011), "Filing strategies and patent value", Economics of Innovation and New Technology, Vol. 20 No. 6, pp. 539-561.

Veer, T. and Jell, F. (2012), "Contributing to markets for technology? A comparison of patent filing motives of individual inventors, small companies and universities", Technovation, Vol. 32 Nos 9-10, pp. 513-522.

Zhang, Y. and Wiersema, M.F. (2009), "Stock market reaction to CEO certification: the signaling role of CEO background”, Strategic Management Journal, Vol. 30 No. 7, pp. 693-710.

Zhou, W., Hu, H. and Zey, M. (2015), "Team composition of new venture founding teams: does personality matter?", International Journal of Entrepreneurial Behavior and Research, Vol. 21 No. 5, pp. 673-689.

Zhou, H., Sandner, P.G., Martinelli, S.L. and Block, J.H. (2016), "Patents, trademarks, and their complementarity in venture capital funding", Technovation, Vol. 47, pp. 14-22. 
Appendix

\begin{tabular}{|c|c|c|c|c|c|}
\hline Regressor & Model 1 & Model 2 & Model 3 & Model 4 & portfolios \\
\hline famDum & $0.171^{* *}$ & & & & \\
\hline cumulFamNbr & $(0.070)$ & $\begin{array}{l}0.107^{* *} \\
(0.042)\end{array}$ & $\begin{array}{c}0.091 \\
(0.071)\end{array}$ & $\begin{array}{c}0.084 \\
(0.071)\end{array}$ & 719 \\
\hline \multicolumn{6}{|l|}{ Complexity measures } \\
\hline inventors $\mathrm{Nbr}$ & & & $\begin{array}{r}-0.013 \\
(0.042)\end{array}$ & $\begin{array}{r}-0.015 \\
(0.042)\end{array}$ & \\
\hline techScope & & & $\begin{array}{c}-0.038 \\
(0.072)\end{array}$ & $\begin{array}{c}-0.034 \\
(0.072)\end{array}$ & \\
\hline bwdPatCitsNbr & & & $\begin{array}{c}0.001 \\
(0.003)\end{array}$ & $\begin{array}{c}-0.001 \\
(0.004)\end{array}$ & \\
\hline bwdPubCitsPerc & & & $\begin{array}{c}-0.262 \\
(0.389)\end{array}$ & $\begin{array}{c}-0.243 \\
(0.390)\end{array}$ & \\
\hline \multicolumn{6}{|l|}{ Quality measures } \\
\hline assigneesNbr & & & $\begin{array}{l}0.179 * * \\
(0.081)\end{array}$ & $\begin{array}{l}0.181 * * \\
(0.080)\end{array}$ & \\
\hline geoScope & & & $\begin{array}{l}0.039 * \\
(0.023)\end{array}$ & $\begin{array}{c}0.034 \\
(0.023)\end{array}$ & \\
\hline weiFwdCitsNbr & & & & $\begin{array}{l}0.086^{*} \\
(0.051)\end{array}$ & \\
\hline \multicolumn{6}{|l|}{ Control variables } \\
\hline pastFinAmt & $\begin{array}{l}0.009 * * * \\
(0.003)\end{array}$ & $\begin{array}{l}0.009 * * * \\
(0.003)\end{array}$ & $\begin{array}{l}0.011^{* * * *} \\
(0.002)\end{array}$ & $\begin{array}{l}0.011^{* * * *} \\
(0.002)\end{array}$ & \\
\hline firmAgeAtDeal & $\begin{array}{c}0.011 \\
(0.012)\end{array}$ & $\begin{array}{c}0.009 \\
(0.012)\end{array}$ & $\begin{array}{c}-0.015 \\
(0.017)\end{array}$ & $\begin{array}{c}-0.015 \\
(0.017)\end{array}$ & \\
\hline Time, sector, geo dummies & Yes & Yes & Yes & Yes & \\
\hline Round dummies & Yes & Yes & Yes & Yes & \\
\hline Constant & $\begin{array}{l}-1.434 \\
(26.900)\end{array}$ & $\begin{array}{l}-4.001 \\
(26.746)\end{array}$ & $\begin{array}{c}60.405^{*} \\
(35.620)\end{array}$ & $\begin{array}{c}52.129 \\
(35.716)\end{array}$ & \\
\hline Sigma & $\begin{array}{l}1.010^{* * * *} \\
(0.025)\end{array}$ & $\begin{array}{l}1.009 \text { **** } \\
(0.025)\end{array}$ & $\begin{array}{l}0.944 * * * * \\
(0.040)\end{array}$ & $\begin{array}{l}0.942^{* * * *} \\
(0.040)\end{array}$ & \\
\hline Observations & 1,988 & 1,988 & 726 & 726 & \\
\hline Log-pseudolikelihood & $-2,843$ & $-2,841$ & -988.1 & -987 & \\
\hline Pseudo $R$-squared & 0.188 & 0.189 & 0.167 & 0.168 & \\
\hline $\begin{array}{l}\text { Note(s): The dependent var } \\
\text { parentheses. Models } 1 \text { and } \\
\text { subsample of companies wit } \\
5 \% \text {, and * as } 10 \%\end{array}$ & $\begin{array}{l}\text { the logarithm } \\
\text { sted on the } f \\
\text { st one patent. }\end{array}$ & $\begin{array}{l}\text { financed amo } \\
\text { aple of compe } \\
\text { gnificance les }\end{array}$ & $\begin{array}{l}\text { ust standard } \\
\text { lodels } 3 \text { and } \\
\text { represented b }\end{array}$ & $\begin{array}{l}\text { are shown in } \\
\text { sted on the } \\
\text { s } 1 \%, * * \text { as }\end{array}$ & $\begin{array}{r}\text { Table A1. } \\
\text { Results of the Tobit } \\
\text { model with left } \\
\text { censoring }\end{array}$ \\
\hline
\end{tabular}

How VCs evaluate YIC patent

719
Complexity measures

inventors $\mathrm{Nbr}$ br

bwdPubCitsPerc

\section{Quality measures}

geoscope

weiFwdCitsNbr

\section{Control variables \\ firmAgeAtDeal}

Constant

$$
\begin{gathered}
(0.002) \\
-0.015 \\
(0.017) \\
\text { Yes } \\
\text { Yes } \\
52.129 \\
(35.716) \\
0.942^{* * * *} \\
(0.040) \\
726 \\
-987 \\
0.168
\end{gathered}
$$
(1) 
IJEBR
26,4

720

Table A2.

Regression results, subsamples of sectors with high and low patent intensity (sensitivity test on the exclusion of sectors near the threshold that distinguishes low and high appropriability and of the sector education)

\begin{tabular}{|c|c|c|c|c|c|c|}
\hline \multirow[t]{2}{*}{ Regressor } & Model 1 & Model 2 & Model 3 & Model 4 & Model 5 & Model 6 \\
\hline & \multicolumn{3}{|c|}{ Low appropriability sectors } & \multicolumn{3}{|c|}{ High appropriability sectors } \\
\hline famDum & $\begin{array}{c}0.070 \\
(0.110)\end{array}$ & & & $\begin{array}{l}0.411 \text { **** } \\
(0.140)\end{array}$ & & \\
\hline cumulFamNbr & & $\begin{array}{c}0.006 \\
(0.080)\end{array}$ & $\begin{array}{c}-0.178 \\
(0.126)\end{array}$ & & $\begin{array}{l}0.257^{* * * *} \\
(0.060)\end{array}$ & $\begin{array}{l}0.258^{* * *} \\
(0.100)\end{array}$ \\
\hline
\end{tabular}

Complexity measures

inventors Nbr

0.033

$(0.060)$

techScope

0.072

(0.120)

bwdPatCitsNbr

$-0.011$

(0.014)

bwdPubCitsPerc

$-1.053$

(0.710)

$-0.055$

(0.064)

$-0.075$

(0.083)

$-0.000$

(0.004)

$-0.520$

(0.916)

Quality measures

assignees $\mathrm{Nbr}$

0.157

0.299

(0.183)

$(0.226)$

0.037

(0.067)

weiFwdCitsNbr

$-0.028$

(0.103)

0.051

$(0.032)$

0.060

(0.117)

Control variables pastFinAmt

$0.007^{* *}$
$(0.004)$
$0.041^{* *}$
$(0.017)$
Yes
Yes
-0.011
$(40.296)$
969
0.533
0.523

$\begin{array}{ccc}0.007 * * & 0.015 * * * & 0.011^{* * * *} \\ (0.004) & (0.002) & (0.003) \\ 0.043^{* *} & 0.040 & -0.025 \\ (0.018) & (0.038) & (0.022) \\ \text { Yes } & \text { Yes } & \text { Yes } \\ \text { Yes } & \text { Yes } & \text { Yes } \\ 2.260 & 84.005 & 64.560 \\ (40.508) & (81.465) & (54.334) \\ 969 & 178 & 477 \\ 0.533 & 0.535 & 0.374 \\ 0.523 & 0.469 & 0.354\end{array}$

$0.008^{* * * *}$
$(0.003)$
-0.032
$(0.021)$
Yes
Yes
54.162
$(51.493)$
477
0.395
0.375

$0.007^{* * * *}$

(0.002)

$-0.051^{* * *}$

(0.024)

Yes

Yes

Round sumies

Constant

Observations

$R$-squared

0.523

0.469

Note(s): The dependent variable is the logarithm of the financed amount. Robust standard errors are shown in parentheses. Models 1 to 3 and 4 to 6 are tested on the low and high appropriability sectors, respectively. Models 3 and 6 are tested on the subsample of companies holding at least one patent. The significance levels are represented by $* * *$ as $1 \%$, ** as $5 \%$, and $*$ as $10 \%$ 


\begin{tabular}{|c|c|c|c|c|c|c|c|}
\hline Regressor & Model 1 & $\begin{array}{c}\text { Model } 2 \\
\text { Excl. UK firms }\end{array}$ & Model 3 & $\begin{array}{l}\text { Model } 4 \\
\text { Excl. Inter }\end{array}$ & $\begin{array}{c}\text { Model } 5 \\
\text { net and Softwar }\end{array}$ & $\begin{array}{l}\text { Model } 6 \\
\text { e, Mobile }\end{array}$ & $\begin{array}{r}\text { How VCs } \\
\text { evaluate YIC }\end{array}$ \\
\hline famDum & $\begin{array}{l}0.203^{* *} \\
(0.088)\end{array}$ & & & $\begin{array}{c}-0.186 \\
(0.144)\end{array}$ & & & portfolios \\
\hline cumulFamNbr & & $\begin{array}{l}0.122^{* *} \\
(0.049)\end{array}$ & $\begin{array}{c}0.094 \\
(0.070)\end{array}$ & & $\begin{array}{c}-0.098 \\
(0.099)\end{array}$ & $\begin{array}{c}0.076 \\
(0.368)\end{array}$ & \\
\hline \multirow{2}{*}{$\begin{array}{l}\text { Complexity measures } \\
\text { inventors Nbr }\end{array}$} & & & & & & & 121 \\
\hline & & & $\begin{array}{c}0.000 \\
(0.046)\end{array}$ & & & $\begin{array}{c}-0.062 \\
(0.119)\end{array}$ & \\
\hline techScope & & & $\begin{array}{c}-0.139 \\
(0.089)\end{array}$ & & & $\begin{array}{r}0.216 \\
(0.247)\end{array}$ & \\
\hline bwdPatCitNbr & & & $\begin{array}{c}-0.014^{* * *} \\
(0.006)\end{array}$ & & & $\begin{array}{r}-0.010 \\
(0.024)\end{array}$ & \\
\hline bwdPubCitsPerc & & & $\begin{array}{c}-0.160 \\
(0.409)\end{array}$ & & & $\begin{array}{c}-0.537 \\
(1.053)\end{array}$ & \\
\hline \multicolumn{8}{|l|}{ Quality measures } \\
\hline assignees Nbr & & & $\begin{array}{l}0.194^{* *} \\
(0.089)\end{array}$ & & & $\begin{array}{c}0.749^{*} \\
(0.431)\end{array}$ & \\
\hline geoScope & & & $\begin{array}{c}0.036 \\
(0.030)\end{array}$ & & & $\begin{array}{c}0.169 \\
(0.139)\end{array}$ & \\
\hline weiFwdCitsNbr & & & $\begin{array}{l}0.205^{* * * *} \\
(0.065)\end{array}$ & & & $\begin{array}{r}-0.104 \\
(0.183)\end{array}$ & \\
\hline \multicolumn{8}{|l|}{ Controls } \\
\hline pastFinAmt & $\begin{array}{l}0.008 * * * \\
(0.003)\end{array}$ & $\begin{array}{l}0.007 * * * \\
(0.003)\end{array}$ & $\begin{array}{l}0.010 * * * \\
(0.002)\end{array}$ & $\begin{array}{l}0.012^{* * * *} \\
(0.004)\end{array}$ & $\begin{array}{l}0.012^{* * * *} \\
(0.004)\end{array}$ & $\begin{array}{l}0.065^{* * * *} \\
(0.024)\end{array}$ & \\
\hline firmAgeAtDeal & $\begin{array}{c}0.005 \\
(0.014)\end{array}$ & $\begin{array}{l}0.004 \\
(0.014)\end{array}$ & $\begin{array}{r}-0.016 \\
(0.020)\end{array}$ & $\begin{array}{c}0.008 \\
(0.032)\end{array}$ & $\begin{array}{c}0.009 \\
(0.032)\end{array}$ & $\begin{array}{c}-0.040 \\
(0.080)\end{array}$ & \\
\hline $\begin{array}{l}\text { Time, sector, geo } \\
\text { dummies }\end{array}$ & Yes & Yes & Yes & Yes & Yes & Yes & \\
\hline Round dummies & Yes & Yes & Yes & Yes & Yes & Yes & \\
\hline Constant & $\begin{array}{r}-10.893 \\
(33.803)\end{array}$ & $\begin{array}{r}-11.188 \\
(33.818)\end{array}$ & $\begin{array}{c}41.544 \\
(44.588)\end{array}$ & $\begin{array}{c}-161.386^{* * *} \\
(69.581)\end{array}$ & $\begin{array}{c}-161.972^{* * *} \\
(70.428)\end{array}$ & $\begin{array}{l}-74.889 \\
(246.990)\end{array}$ & \\
\hline Observations & 1,286 & 1,286 & 458 & 276 & 276 & 61 & \\
\hline$R$-squared & 0.502 & 0.503 & 0.452 & 0.634 & 0.633 & 0.691 & \\
\hline $\begin{array}{l}\text { Adjusted } R- \\
\text { squared }\end{array}$ & 0.491 & 0.492 & 0.412 & 0.606 & 0.605 & 0.513 & \\
\hline \multicolumn{7}{|c|}{$\begin{array}{l}\text { Note(s): The dependent variable is the logarithm of the financed amount. Robust standard errors are shown in } \\
\text { parentheses. Models } 1 \text { to } 3 \text { analyze the subsample that exclude the most frequent country (United Kingdom). } \\
\text { Models } 4 \text { to } 6 \text { focus on the sub-sample of low appropriability sectors and exclude the two most frequent sectors } \\
\text { ("Internet", "Software and Mobile"). The significance levels are represented by *** as } 1 \%, * * \text { as } 5 \% \text {, and * } \\
\text { as } 10 \%\end{array}$} & $\begin{array}{r}\text { Regression results, } \\
\text { robustness tests on } \\
\text { subsamples excluding } \\
\text { the most frequent } \\
\text { country and the sectors }\end{array}$ \\
\hline
\end{tabular}

\section{Corresponding author}

Antonio De Marco can be contacted at: antonio.demarco@polito.it

For instructions on how to order reprints of this article, please visit our website:

www.emeraldgrouppublishing.com/licensing/reprints.htm

Or contact us for further details: permissions@emeraldinsight.com 